International Journal of English Literature and Social Sciences
Vol-6, Issue-3; May-Jun, 2021

Peer-Reviewed Journal

\title{
Academic Teaching Skills: Determining the methods of teaching to undergraduate students
}

\author{
Bayad Jamal Ali ${ }^{1}$, Govand Anwar ${ }^{2}$
}

\author{
${ }^{1}$ Business Administration Department, Komar University of Science and Technology, Sulaimani 46001, Kurdistan Region - Iraq \\ ${ }^{2}$ Department of Business Administration, College of Administration and Financial Sciences, Knowledge University, 44001 Erbil, \\ Kurdistan Region, Iraq
}

Received: 22 Feb 2021; Received in revised form: 22 Apr 2021; Accepted: 18 May 2021; Available online: 04 Jun 2021 (C)2021 The Author(s). Published by Infogain Publication. This is an open access article under the CC BY license (https://creativecommons.org/licenses/by/4.0/).

\begin{abstract}
This work aims to investigate different teaching ethics methodologies for university graduate students in order to recognize and prevent fraud in all sectors of industry because they will get involved in the industry following their study at the University. There are various arguments against the concept that university graduate students are included in the paper. In practically everyone industry, there are many fraud occurrences because of educated professionals that have no sense of ethical standards that are associated with their career except for iliterate fraudsters. Each industry has established its ethical rules that will give guidance to professionals who execute them in everyday life. A study at a private university was conducted. A quantitative way for analyzing this paper. In order to analyze this study, a questionnaire was carried out. In the private university of Erbil, 170 questionnaires were distributed, 158 were received, however of the 158 questionnaires, only 146 were valid and completed properly. According to several regression analyzes, traditional lectures had the highest value. A classic lecture is one of the ways that can achieve educational objectives.
\end{abstract}

Keywords - Business ethics, teaching strategies, Private Universities, Kurdistan.

\section{INTRODUCTION}

The Teaching Ethics course to university graduates requires certain tactics to make them aware, apart from technical capabilities (Ali, 2014), of the necessity to be ethical. The task of communicating ethical ideals in the minds of students through curricula from various fields (Ali et al. 2021) lies with subject matter experts as well as faculty members who teach this specific course (Anwar \& Abd Zebari, 2015). Teaching options for graduate students' ethics are standard lectures (Top \& Ali, 2021), role-playing, case study and help from professionals with professional ethics difficulties (Sorguli et al. 2021). The research also identifies the teaching ethical process (Saleh et al. 2021). According to (Sabir et al. 2021), the use of ethicalists has knowledge and finite resources complications can be helpful (Jamal et al. 2021). It is recommended that a professor in the discipline involved may be trained and prepared for the duty of teaching ethics (Ismael et al. 2021).
Accounting faculty member in business training is competent for teaching Blanthorne (Hamza et al. 2021). As members in an ethical organization (Hameed \& Anwar, 2018), organizations are not obliged to participate which effect individual ethical behavior within the organization (Faraj et al. 2021). The American Institute of Public Accountants Certified (AICPA) has provided Certified Professional Accountants (CPA) and its members with rules on ethics (Demir et al. 2020). While drawing up the ethical guidelines of organizations that oversee the business (Aziz et al. 2021), it was considered how decision makers and end users of the sector observe a particular profession (Anwar, K., \& Louis, 2017). According to (Anwar, 2017), it would be conceivable to include ethics courses in the curriculum for university graduates in two ways (Anwar, 2016). One option is to teach separate courses, which are individually personalized (Anwar \& Surarchith, 2015). The second option is to teach ethics across the curriculum, which 
requires a professor who teaches this particular course to know about it (Anwar \& Shukur, 2015). According to F (Anwar \& Qadir, 2017), the Academy of Accounting has reduced its expertise and recommended finding strategies to teach ethics to teach them (Anwar \& Ghafoor,2017). The Sirotnik Teacher Education (1990) is a method in which moral character is bestowed rather than competence and expertise (Anwar \& Climis, 2017), where both are vital (Anwar \& Balcioglu, 2016). Ethics can be easily taught when a pupil is expected to perform rather than simply memorize him/her (Anwar \& Abdullah, 2021). Many experiments and theories have been developed on teaching students and bringing actual value from students (Anwar \& Abd Zebari, 2015).

\section{LITERATURE REVIEW}

The fields of education and methodology in education may be varied (Andavar et al. 2020), but they all share the fundamental common notion that the student understands the idea (Ali, 2014), uses it in real life and follows the ethical norms in the subject chosen (Ali et al. 2021). According to (Ali et al. 2021), teachers planned in advance give higher results than ordinary techniques (Ali \& Anwar, 2021). Research by McGee and Bruce Howard emphasized that traditional approaches do not create a competitive environment and class as a whole (Akoi et al. 2021). The students' solitary demands may not be satisfied by a single technique of teaching since they have numerous queries with relation to teaching concepts and their attention will be divergent (Ahmed et al. 2021). The objective of any student evaluation approach is to make the student grasp the concept instead of testing their memory's capacity to retain the subject like (Abdullah et al. 2021). According to (Hameed \& Anwar, 2018), learning tasks that affect different kinds of knowledge production and student participation in the course curriculum would be the key role in obtaining learning results in a technologically oriented setting (Faraj et al. 2021). According to (Demir et al. 2020), students, teachers, through education as a media, affect each other's lives, while others participate in this process (Aziz et al. 2021). A student has to have critical thinking and awareness of ethical concerns that are crucial for him/her during his/her studies and when he/she becomes a member of a professional organization (Anwar, K., \& Louis, 2017). (Anwar, 2017) indicates that students are taught ethicscentered courses that will prepare them for tough alternatives and that they should have an interest in learning facts of dilemma (Anwar, 2016). The character of ethics in education is the behavior of persons to provide human beings with a benefit according to (Anwar \& Surarchith, 2015). The membership of persons in a profession will involve customers in making basic demands, and the demands of customers and interests are paramount than the requirement of the provider (Anwar \& Shukur, 2015). (Anwar \& Qadir, 2017), parents and relatives are responsible for a student's moral instruction early on, which will lead to the student's wonderful behavior towards parents and other persons (Anwar \& Ghafoor,2017). (Anwar \& Climis, 2017)has concluded that codes can guide employee decision-making and shape their ethical conduct (Anwar \& Balcioglu, 2016).

\section{METHODOLOGY}

\section{Design of the study}

To assess the current study, the researchers used a questionnaire. Divided into two main areas, the first part was demographic analysis, beginning with the age, gender and level of education of the respondents. The second questionnaire consisted of four sub-sections; the first subsection dealt in case study as a dependent factor; the second with the traditional lecture teaching method as an independent variable; the third sub-section with the method of teaching the assignment; and the last sub-section with the course in business ethics as a dependent variable.

\section{Sampling Size}

The research sample was recruited using a random sampling approach. The aforementioned random selection took place in Erbil's private university. In the private university of Erbil a total of 170 questionnaires were distributed, 158 were received, but only 146 were valid and fully completed out of 158 questionnaires. The data have been obtained in hard copies.

\section{Instrument for measuring (scales)}

In order to explore the feature of business ethics learning, this study investigates the evaluation of the teaching method of case study, the traditional teaching technique, the technique of teaching and the course on business ethics study. Participants were asked to assess how strongly they agree on five ordered measures in each question. The scale of business ethics learning as a dependent variable was measured and evaluated on a 5-point scale, where potential responses vary strongly to the same scale, and the scales for the case study method, traditional teaching method, and assignment teaching method were measured on a five-point ordered scale, which provided possible answers. These tools were proven by previous scientists to be excellent for the study of instructional practices (Marmah, 2014) and (Ismail, 2014).

\section{Research Model}




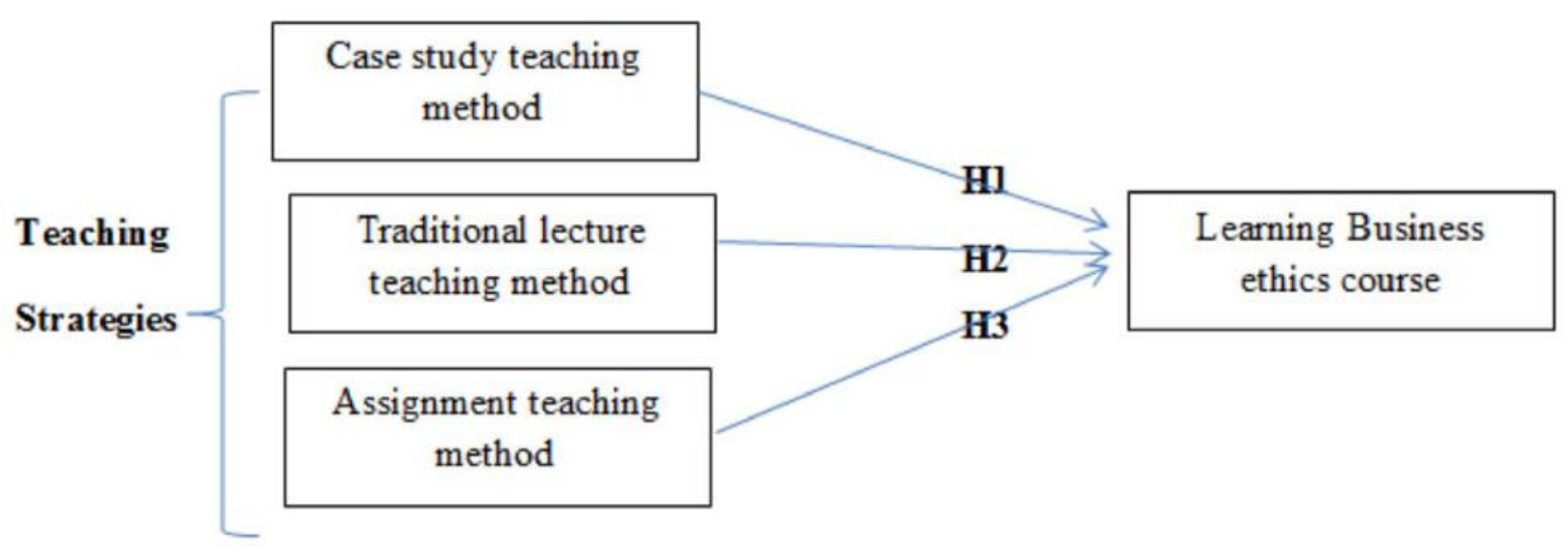

Fig.1: Research Model, created by the researchers

\section{Research hypotheses}

According to the above research model, the researchers set the following research hypothesis: H1: There is a positive association between case study teaching method and learning business ethics course.

$\mathrm{H} 2$ : There is a positive association between traditional lecture teaching method and learning business ethics course.

H3: There is a positive association between assignment teaching method and learning business ethics course.

\section{DATA ANALYSIS AND RESULTS}

The purpose of this study is to measure the relation between teaching strategies (case study teaching method, traditional lecture teaching method and assignment teaching method) with learning business ethics course in private university in Erbil. As it mentioned previously total of 146 participants were involved in completing the survey. These respondents had different level of education some respondents were from first year, some from second year, third year and others from fourth year. The current study deals with learning business ethics and teaching strategies in education sectors, the teaching strategies criteria to examine were identified as case study teaching method, traditional lecture teaching method and assignment teaching method. The participants were asked to rate how important they perceived each item on five point ordered scales. The scales for engineer performance was measured and evaluated on a five point scale with potential answers ranging from strongly disagree to strong agree. The scales for training, performance evaluation, compensation, promotion and participation were measured as well on a five point ordered scale which however gave possible answers ranging from strongly disagree to strongly agree. The following tables show the statistical results of this study using SPSS program:

\section{Demographic Analysis}

Table 1 Demographic Analysis

\begin{tabular}{llcc}
\hline Items & & Frequency & Percent \\
\hline \multirow{2}{*}{ Gender } & Male & 84 & 57.5 \\
& Female & 62 & 42.5 \\
Age & $20-21$ & 13 & 8.9 \\
& $22-23$ & 77 & 52.7 \\
& $24-25$ & 49 & 33.6 \\
Level of & $25+$ & 7 & 4.8 \\
education & Second year & 37 & 25.3 \\
& Third year & 76 & 52.1 \\
& Fourth year & 33 & 22.6 \\
\hline
\end{tabular}


Table 2 Reliability Analysis

\begin{tabular}{ccc}
\hline Factor & Cronbach's Alpha & Number of items \\
\hline Case study method & .768 & 9 \\
Traditional lecture & .867 & 7 \\
method & & \\
Assignment method & .608 & 7 \\
Business ethics & .913 & 9 \\
\hline
\end{tabular}

As seen in the table (2), the reliability analysis for case study method, traditional lecture method and assignment method as independent factors, on the other hand, business ethics course for business department students as dependent factor. According to the reliability statistics test, the researchers found out Cronbach's Alpha for case study teaching method $=.768$ for which is greater than .7 this means that items of case study teaching method factor was reliable for this study, Cronbach's Alpha for traditional lecture teaching method $=.867$ for which is greater than .7 this means that items of traditional lecture teaching method was reliable for this study, Cronbach's Alpha for assignment teaching method $=.608$ which is greater than .7 this means that items of assignment teaching method was reliable for this study and Cronbach's Alpha for business ethics course $=.9137$ this means that items for the business ethics course was reliable for this study.

Table 3 Correlation Analysis

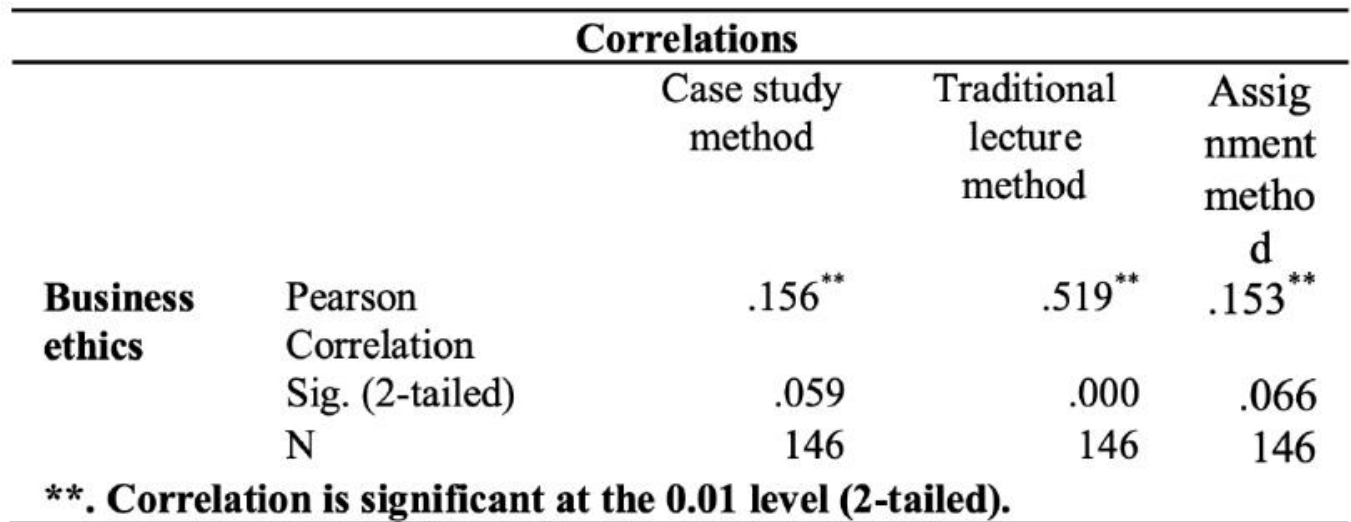

As seen in table (3), $\mathrm{R}=.156^{* *}$ for case study teaching method factor, this means that case study teaching method has weak correlated with business ethics course, $\mathrm{R}=.519 * *$ for traditional lecture teaching method factor, this means that traditional lecture teaching method has significantly correlated with business ethics course and $\mathrm{R}=.153 * *$ for assignment teaching method factor, this means that assignment teaching method has weak correlated with business ethics course. According to the above table, the researchers concluded the strongest correlation and the highest value among all factors was traditional lecture teaching method which $=.519 * *$.

Table 4 Model Summary

\begin{tabular}{|c|c|c|c|c|}
\hline \multicolumn{5}{|c|}{ Model Summary } \\
\hline $\begin{array}{l}\text { Mod } \\
\text { el }\end{array}$ & $\mathrm{R}$ & R Square & $\begin{array}{l}\text { Adjusted R } \\
\text { Square }\end{array}$ & $\begin{array}{l}\text { Std. Error of } \\
\text { the Estimate }\end{array}$ \\
\hline 1 & $.524^{\mathrm{a}}$ & .275 & .260 & .90001 \\
\hline a. $\mathbf{P}$ & s: $:(C$ & t), assignm & aditional, ca & \\
\hline
\end{tabular}

Regression analysis is analyzing relationships among factors. $\mathrm{Y}=\mathrm{f}(\mathrm{x} 1, \mathrm{x} 2 \ldots \mathrm{XC})$. Regression analysis is to estimate the how $\mathrm{Y}$ will influence and change $\mathrm{X}$ and predict. In this research case study teaching method, traditional lecture teaching method and assignment teaching method are independent variables and business ethics course is dependent. The business ethics course' overall difference could be measured by its variance. The differences are 
measured as the sum of the square between participant's forecasted business ethics course values and the total mean divided by the number of participants. After division it will clarify variance by the total variance of business ethics course, the researchers found out the amount or the number of total difference or variance that is accounted based on regression calculation. The number should vary between 0 -1 and is symbolized by R Square. Table (4) shows the value of $\mathrm{R}$ square $=.275$ this indicates that $27.5 \%$ of total variance has been explained.

Table 5 ANOVA

\begin{tabular}{|c|c|c|c|c|c|c|}
\hline \multicolumn{7}{|c|}{ ANOVA $^{\mathrm{a}}$} \\
\hline \multicolumn{2}{|c|}{ Model } & Sum of Squares & $\mathrm{df}$ & $\begin{array}{l}\text { Mean } \\
\text { Sauare }\end{array}$ & $\mathrm{F}$ & Sig. \\
\hline \multirow[t]{3}{*}{1} & $\begin{array}{l}\text { Regres } \\
\text { sion }\end{array}$ & 43.592 & 3 & 14.531 & $\begin{array}{r}17.93 \\
9\end{array}$ & .000 \\
\hline & $\begin{array}{l}\text { Residu } \\
\text { al }\end{array}$ & 115.022 & 142 & .810 & & \\
\hline & Total & 158.614 & 145 & & & \\
\hline
\end{tabular}

As seen in the above table (5), F value for case study teaching method, traditional lecture teaching method and assignment teaching method as independent variable $=17.939$, since $(17.939>1)$ this indicates there is a significant relation between all independent variables (case study teaching method, traditional lecture teaching method and assignment teaching method) and dependent variable which is business ethics course.

Table 6 Coefficients

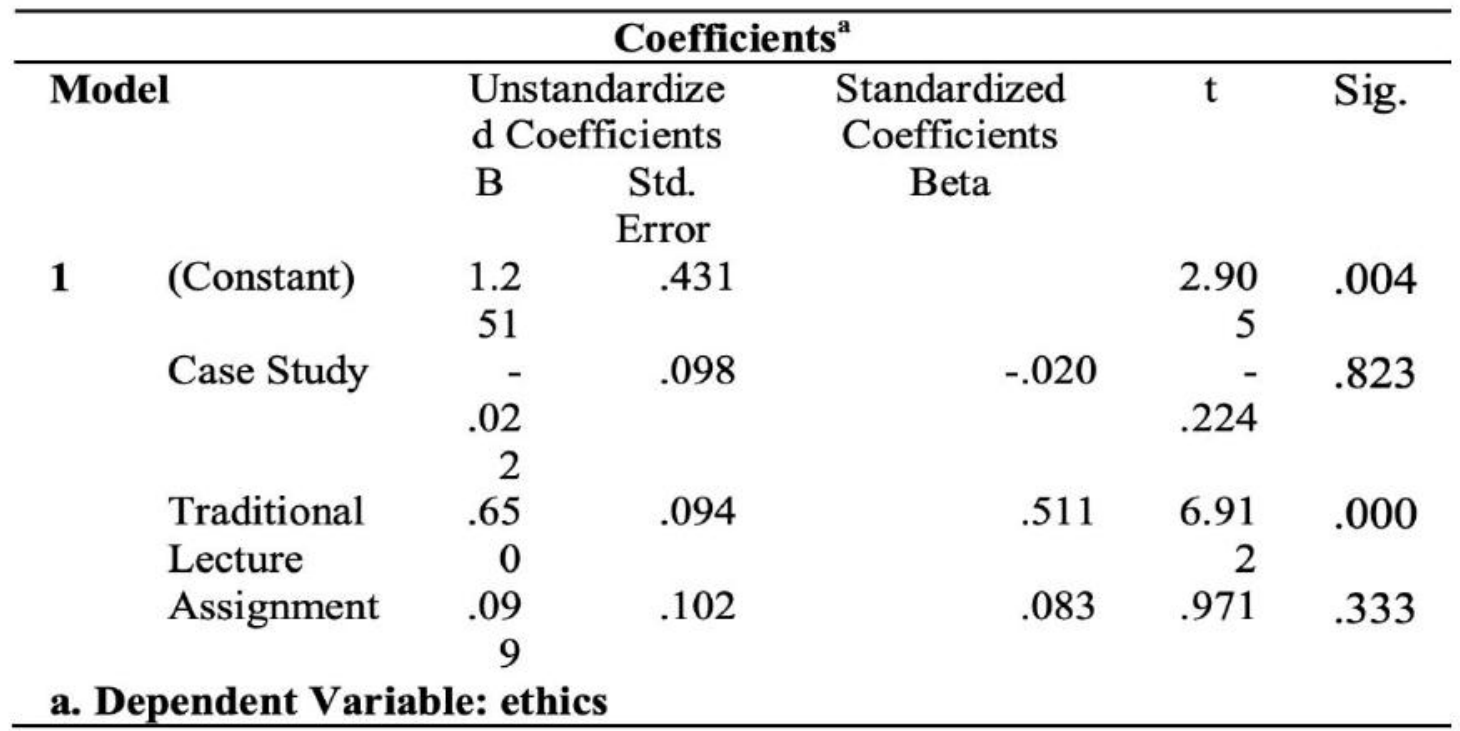

As seen in the above table (6), the result of three hypothesis, case study has not predicted business ethics course ( Beta is weight $-0.20, \mathrm{p}>.001$ ) this indicates that case study teaching method will not have any association with learning business ethics course, accordingly the first research hypothesis was rejected. According to traditional lecture teaching method has significantly predicted learning business ethics course (Beta is weight 0.511,p.001) this indicates that assignment teaching method will have a weak positive association with 
learning business ethics course, accordingly third research hypothesis was supported.

\section{CONCLUSIONS}

The study has proved the extensively held opinion that the traditional lecture method will pursue to be the principal method of teaching in education sectors. According to multiple regression analysis, the researchers found out that the highest value and the most dominant teaching method was traditional lecture method. The findings of this study proved the strongest relation between traditional lecture teaching methods with learning business ethics course. Also, based on multiple regression analysis, the researchers were able to test the research hypothesis; the first research hypothesis; case study teaching method has a positive association with learning business ethics course, the finding of this study revealed that case study teaching method has not predicted business ethics course ( Beta is weight -0.20 , p>.001) this indicates that case study teaching method will not have any association with learning business ethics course, accordingly the first research hypothesis was rejected. The second research hypothesis; traditional lecture teaching method has positive association with learning business ethics course, the finding of this study revealed that traditional lecture teaching method has significantly predicted learning business ethics course (Beta is weight 0.511, p.001) this indicates that assignment teaching method will have a weak positive association with learning business ethics course, accordingly third research hypothesis was supported.

\section{REFERENCES}

[1] Top, C., \& Ali, B. J. (2021). Customer satisfaction in online meeting platforms: Impact of efficiency, fulfillment, system availability, and privacy. Amazonia Investiga, 10(38), 70 81. https://doi.org/10.34069/AI/2021.38.02.7

[2] Demir, A., Maroof, L., Sabbah Khan, N.U. and Ali, B.J. (2020), "The role of E-service quality in shaping online meeting platforms: a case study from higher education sector", Journal of Applied Research in Higher Education. https://doi.org/10.1108/JARHE-08-2020-0253

[3] Ali, B, J. (2021). Impact of consumer animosity, boycott participation, boycott motivation, and product judgment on purchase readiness or aversion of Kurdish consumers in Iraq. Journal of Consumers Affaires; 1-20. https://doi.org/10.1111/joca. 12350

[4] Ali, B, J. (2020). Impact of COVID-19 on consumer buying behavior toward online shopping in Iraq. Economic studies journal. 18(42): 267-280. Retrieved from https://www.asjp.cerist.dz/en/article/134070

[5] Ali, B.J. (2021) Assessing (The impact) of advertisement on customer decision making: Evidence from an educational institution. Afak for sciences journal, 6(1): 425-439. Retrieved from https://www.asjp.cerist.dz/en/article/141056

[6] Ali, B.J. (2021) Consumer attitudes towards healthy and organic food in the Kurdistan region of Iraq. Management Science Letters. 11: 1-8. DOI: 10.5267/j.msl.2021.2.015

[7] Andavar, V., Ali, B.J., and Ali, S.A. (2020) Rainwater for Water Scarcity Management: An Experience of Woldia University (Ethiopia). Journal of Business, Economics and Environmental Studies, 10-(4): 29-34. DOI: 10.13106/jbees.2020.vol10.no4.29

[8] Faraj, K. M., Faeq, D. K., Abdulla, D. F., Ali, B. J., \& Sadq, Z. M. (2021). Total Quality Management And Hotel Employee Creative Performance: The Mediation Role Of Job Embeddedment. Journal of Contemporary Issues in Business and Government, 27(1), 3838-3855. http://dx.doi.org/10.47750/cibg.2021.27.01.001

[9] Ali, B. J. (2016). Iraq Stock Market and its Role in the Economy. Retrieved from https://www.amazon.com/IraqStock-Market-Role-Economy/dp/3659634271

[10] Ali, B. J. (2014). Brand Building in the Consumer Electronics Industry in Iraq. Retrieved from https://www.amazon.com/Brand-Building-ConsumerElectronics-Industry/dp/6200248699

[11] Ali, B. J., \& Anwar, G. (2021). Factors Influencing the Citizens' Acceptance of Electronic Government. International Journal of Engineering, Business and Management, $5(1), \quad 48-60$. https://doi.org/10.22161/ijebm.5.1.5

[12] Saleh, P. F., Ali, B. J., Akoi, S., Najmalddin, B., Ali, R. S., \& Anwar, G. (2021). Factors affecting the Success of Female Entrepreneurs in Kurdistan. International journal of Engineering, Business and Management (IJEBM), 5.

[13] Ali, B. J., \& Anwar, G. (2021). The Effect of Marketing Culture Aspects of Healthcare Care on Marketing Creativity. International Journal of English Literature and Social Sciences, 6(2), 171-182. https://doi.org/10.22161/ijels.62.25

[14] Ali, B. J., \& Anwar, G. (2021). An Empirical Study of Employees' Motivation and its Influence Job Satisfaction. International Journal of Engineering, Business and Management, 5(2), 21-30. https://doi.org/10.22161/ijebm.5.2.3

[15] Ali, B. J., Saleh, P. F., Akoi, S., Abdulrahman, A. A., Muhamed, A. S., Noori, H. N., \& Anwar, G. (2021, May). Impact of Service Quality on the Customer Satisfaction: Case study at Online Meeting Platforms. In Ali, BJ, Saleh, Akoi, S., Abdulrahman, AA, Muhamed, AS, Noori, HN, Anwar, G.(2021). Impact of Service Quality on the Customer Satisfaction: Case study at Online Meeting Platforms. International journal of Engineering, Business and Management (Vol. 5, No. 2, pp. 65-77).

[16] Ali, B. J., \& Anwar, G. (2021). The balanced scorecard's evolution as a strategic mechanism at banking sectors. International Journal of English Literature and Social Sciences, $\quad 6(1), \quad 471-478$. https://doi.org/10.22161/ijels.61.63

[17] Anwar, G., \& Abdullah, N. N. (2021). Inspiring future entrepreneurs: The effect of experiential learning on the 
entrepreneurial intention at higher education. International Journal of English Literature and Social Sciences, 6.

[18] Ali, B. J., \& Anwar, G. (2021). Measuring competitive intelligence Network and its role on Business Performance. International Journal of English Literature and Social Sciences, 6(2), 329-345. https://dx.doi.org/10.22161/ijels.62.50

[19] Anwar, G., \& Abdullah, N. N. (2021). The impact of Human resource management practice on Organizational performance. International journal of Engineering, Business and Management (IJEBM), 5.

[20] Abdullah, N. N., \& Anwar, G. (2021). An Empirical Analysis of Natural Gas as an Alternative Fuel for Internal Transportation. International Journal of English Literature and Social Sciences, 6(1).

[21] Ali, B. J., \& Anwar, G. (2021). A study of knowledge management alignment with production management: A study of carpet manufacture in Kurdistan region of Iraq. International Journal of English Literature and Social Sciences, 6(2), 346-360. https://dx.doi.org/10.22161/ijels.62.51

[22] Ali, B. J., \& Anwar, G. (2021). The mediation role of change management in employee development. International Journal of English Literature and Social Sciences, 6(2), 361374. https://dx.doi.org/10.22161/ijels.62.52

[23] Anwar, K., \& Louis, R. (2017). Factors Affecting Students' Anxiety in Language Learning: A Study of Private Universities in Erbil, Kurdistan. International Journal of Social Sciences \& Educational Studies, 4(3), 160.

[24] Ali, B. J., \& Anwar, G. (2021). Business strategy: The influence of Strategic Competitiveness on competitive advantage. International Journal of Electrical, Electronics and Computers, 6(2), 1-10. https://dx.doi.org/10.22161/eec.62.1

[25] Anwar, K. (2017). Leading Construction Project Teams: The Effectiveness of Transformational Leadership in Dynamic Work Environments in Kurdistan. International Journal of Advanced Engineering, Management and Science, 3(10), 239925.

[26] Ali, B. J., \& Anwar, G. (2021). Strategic leadership effectiveness and its influence on organizational effectiveness. International Journal of Electrical, Electronics and Computers, 6(2), 11-24. https://dx.doi.org/10.22161/eec.62.2

[27] Anwar, K., \& Qadir, G. H. (2017). A Study of the Relationship between Work Engagement and Job Satisfaction in Private Companies in Kurdistan. International Journal of Advanced Engineering, Management and Science, 3(12), 239944.

[28] Ali, B. J., \& Anwar, G. (2021). Intellectual capital: A modern model to measure the value creation in a business. International journal of Engineering, Business and Management, 5(2), 31-43. https://dx.doi.org/10.22161/ijebm.5.2.4

[29] Ali, B. J., \& Anwar, G. (2021). Marketing Strategy: Pricing strategies and its influence on consumer purchasing decision. International journal of Rural Development,
Environment and Health Research, 5(2), 26-39. https://dx.doi.org/10.22161/ijreh.5.2.4

[30] Anwar, K. (2017). Factors Affecting Stock Exchange Investment In Kurdistan. The International Journal of Accounting and Business Society, 25(1), 32-37.

[31] Ali, B. J., \& Anwar, G. (2021). Organization citizenship behaviour as a determining Factor in Business outcome. International journal of Rural Development, Environment and Health Research, 5(2), 17-25. https://dx.doi.org/10.22161/ijreh.5.2.3

[32] Anwar, K., \& Climis, R. (2017). Analyzing the relationship between types of advertisement and customer choice: a study of retailer stores in erbil. The International Journal of Accounting and Business Society, 25(2), 43-52.

[33] Talim, S.R., Ali, B.J., Top, C. (2021). Elaborating the Antecedents of Purchase Intentions in Second-Hand Car Industry: Case Study in Kurdistan Region of Iraq. Journal of Contemporary Issues in Business and Government, 27(3), 1526-1547. http://dx.doi.org/10.47750/cibg.2021.27.03.204

[34] Anwar, K., \& Ghafoor, C. (2017). Knowledge management and organizational performance: A study of private universities in Kurdistan. International Journal of Social Sciences \& Educational Studies, 4(2), 53.

[35] Ali, B. J., Saleh, Akoi, S., Abdulrahman, A. A., Muhamed, A. S., Noori, H. N., Anwar, G. (2021). Impact of Service Quality on the Customer Satisfaction: Case study at Online Meeting Platforms. International journal of Engineering, Business and Management, 5(2), 65-77. https://dx.doi.org/10.22161/ijebm.5.2.6

[36] Hameed, A. A., \& Anwar, K. (2018). Analyzing the Relationship between Intellectual Capital and Organizational Performance: A Study of Selected Private Banks in Kurdistan. International Journal of Social Sciences \& Educational Studies, 4(4), 39.

[37] Jamal Ali, B., Akoi, S., Fadel Saleh, P., \& Sardar, zhilwan. (2021). Factors Shaping Customer Satisfaction with Residential Flats: Evidence from Sulaymaniyah City. Black Sea Journal of Management and Marketing, 2(2), 1-12. https://doi.org/10.47299/bsjmm.v2i2.69

[38] Akoi, S., Jamal Ali, B., Fadel Saleh, P., Najmalddin, B., Sabah Mustafa, R., Rzgar Abdulmajid, M., \& Rebwar Hama, A. (2021). Elaborating the Characteristics that Affect Buyers in Online Shopping: The Case of Generation Z Girls in Kurdistan Region of Iraq. Black Sea Journal of Management $\begin{array}{llll}\text { and } & \text { Marketing, } & \text { 2(2), } & 42 \quad\end{array}$ https://doi.org/10.47299/bsjmm.v2i2.74

[39] Anwar, K. (2017). The Role of Effective Leadership in Crisis Management: Study of Private Companies in Kurdistan. Qalaai Zanist Scientific Journal, 2(4), 326-338.

[40] Ahmed, S. Y., Ali, B. J., Top, C. (2021). Understanding the Impact of Trust, Perceived Risk, and Perceived Technology on the Online Shopping Intentions: Case Study in Kurdistan Region of Iraq. Journal of Contemporary Issues in Business and $\quad$ Government, 27(3), 2136-2153. http://dx.doi.org/10.47750/cibg.2021.27.03.264

[41] Anwar, K., \& Balcioglu, H. (2016). The relationship between transformational leadership characteristics and effectiveness: A case study of construction companies in 
Erbil. International Journal of Science Technology and Management, 5(2), 250-256.

[42] Sabir, B. Y., Othman, B .J., Gardi, B., Ismael, N. B., Hamza, P. A., Sorguli, S., Aziz, H. M., Ahmed, S. A., Ali, B. J., Anwar, G. (2021). Administrative Decentralization: The Transfer of Competency from The Ministry of Education to General Directorates. International Journal of Rural Development, Environment and Health Research, 5(3), 113. https://doi.org/10.22161/ijreh.5.3.1

[43] Abdullah, M. S., Toycan, M., \& Anwar, K. (2017). The cost readiness of implementing e-learning. CUSTOS E AGRONEGOCIO ON LINE, 13(2), 156-175.

[44] Ali, B. J., Anwar, G., Gardi, B., Othman, B. J., Aziz, H. M., Ahmed, S. A., Hamza, P. A., Ismael, N. B., Sorguli, S., Sabir, B. Y. (2021). Business Communication Strategies: Analysis of Internal Communication Processes. Journal of Humanities and Education Development, 3(3), 16-38. https://doi.org/10.22161/jhed.3.3.4

[45] Anwar, K. (2016). Comparison between cost leadership and differentiation strategy in agricultural businesses. Custos $E$ Agronegocio on Line, 12(2), 212-231.

[46] Ali, B. J., Gardi, B., Othman, B. J., Ismael, N. B., Sorguli, S., Sabir, B. Y., Ahmed, S. A., Hamza, P. A., Aziz, H. M., Anwar, G. (2021). Educational system: The policy of Educational system in Kurdistan Region in public Kindergarten. International Journal of English Literature and Social Sciences, 6(3), 062-071. https://doi.org/10.22161/ijels.63.10

[47] Anwar, K. (2017). Analyzing the conceptual model of service quality and its relationship with guests'satisfaction: a study of hotels in erbil. The International Journal of Accounting and Business Society, 25(2), 1-16.

[48] Aziz, H. M., Othman, B. J., Gardi, B., Ahmed, S. A., Sabir, B. Y., Ismael, N. B., Hamza, P. A., Sorguli, S., Ali, B. J., Anwar, G. (2021). Employee Commitment: The Relationship between Employee Commitment And Job Satisfaction. Journal of Humanities and Education Development, 3(3), 54-66. https://doi.org/10.22161/jhed.3.3.6

[49] Anwar, G., \& Shukur, I. (2015). The Impact of Service Quality Dimensions on Students' Satisfaction. International Journal of Social Sciences \& Educational Studies, 76.

[50] Ali, B. J., Gardi, B., Othman, B. J., Ahmed, S. A., Ismael, N. B., Hamza, P. A., Aziz, H. M., Sabir, B. Y., Anwar, G. (2021). Hotel Service Quality: The Impact of Service Quality on Customer Satisfaction in Hospitality. International Journal of Engineering, Business and Management, $\quad 5(3), \quad 14-28$. https://doi.org/10.22161/ijebm.5.3.2

[51] Anwar, G., \& Surarchith, N. K. (2015). Factors Affecting Shoppers' Behavior in Erbil, Kurdistan-Iraq. International Journal of Social Sciences \& Educational Studies, 1(4), 10.

[52] Sorguli, S., Gardi, B., Othman, B.J., Aziz, H. M., Ahmed, S. A., Sabir, B. Y., Ismael, N. B., Hamza, P. A., Ali, B. J., Anwar, G. (2021) Innovation: Knowledge Management in the Innovating Industries, 6(3), 10-23. https://dx.doi.org/10.22161/eec.63.2
[53] Anwar, G., \& Abd Zebari, B. (2015). The Relationship between Employee Engagement and Corporate Social Responsibility: A Case Study of Car Dealership in Erbil, Kurdistan. International Journal of Social Sciences \& Educational Studies, 2(2), 45.

[54] Hamza, P. A., Othman, B. J., Gardi, B., Sorguli, S., Aziz, H. M., Ahmed, S. A., Sabir, B. Y., Ismael, N. B., Ali, B. J., Anwar, G. (2021). Recruitment and Selection: The Relationship between Recruitment and Selection with Organizational Performance. International Journal of Engineering, Business and Management, 5(3), 1-13. https://doi.org/10.22161/ijebm.5.3.1

[55] Anwar, G., \& Shukur, I. (2015). the impact of recruitment and selection on job satisfaction: Evidence from private school in Erbil. International Journal of Social Sciences \& Educational Studies, 1(3), 4-13.

[56] Ali, B. J., Gardi, B., Othman, B. J., Sabir, B. Y., Sorguli, S., Ismael, N. B., Hamza, P.A., Aziz, H. M., Ahmed, A. A., Anwar, G. (2021). The Role of Shopping Malls on Kurdistan Regional Government's Economy. Journal of Humanities and Education Development, 3(3), 39-53. https://doi.org/10.22161/jhed.3.3.5

[57] Anwar, G., \& Shukur, I. (2015). Job satisfaction and employee turnover intention: A case study of private hospital in Erbil. International Journal of Social Sciences \& Educational Studies, 2(1), 73.

[58] Ahmed, S. A., Othman, B. J., Gardi, B., Sabir, B. Y., Ismael, N. B., Hamza, P. A., Sorguli, S., Aziz, H. M., Ali, B. J., Anwar, G. (2021). Students' Attitudes towards Learning English in the Kurdistan region of Iraq. International Journal of English Literature and Social Sciences, 6(3), 072-087. https://doi.org/10.22161/ijels.63.11

[59] Anwar, G., \& Shukur, I. (2015). The Impact of Training and Development on Job Satisfaction: A Case Study of Private Banks in Erbil. International Journal of Social Sciences \& Educational Studies, 2(1), 65.

[60] Ismael, N. B., Othman, B. J., Gardi, B., Hamza, P. A., Sorguli, S., Aziz, H. M., Ahmed, S. A., Sabir, B. Y., Ali, B. J., Anwar, G. (2021). The Role of Training and Development on Organizational effectiveness. International Journal of Engineering, Business and Management, 5(3), 15-24. https://doi.org/10.22161/ijebm.5.3.3 